\title{
INSIGHT INTO PROSPECTS OF ISLAMIC BANKING: FROM PAST TO PRESENT*
}

\author{
Kaspars KḶAVIŅŠ1 \\ ${ }^{1}$ Riga Technical University, Latvia \\ ${ }^{2}$ Emirates College of Technology, UAE \\ Corresponding author e-mail: klavinskaspars@gmail.com
}

\begin{abstract}
Islamic banking is one of the alternative financial models of the modern world, which is currently gaining more and more international recognition and reliability both in the East and West. The article reveals separate historical aspects of the genesis of Islamic banking in order to better demonstrate the potential of this financial system now and in the future. The purpose of the research is to highlight the ability of Islamic banking to integrate into the western-dominated economy and society.
\end{abstract}

Keywords: Alternative, financial crisis, riba, social security.

\section{INTRODUCTION}

Although Islamic banking is a relatively new player in the global financial world, this system has very old roots and extraordinary bright prospects for the future. The biggest error of modern scientists is the discussion of economic processes without the cultural and historical, religious and philosophical context. Only by looking at all of these aspects one can understand the prospects of different traditions under the changing conditions of today. Despite the fact that the genesis of Islamic banking is closely linked to the cultural, historical and economic tradition of the Middle East, it is absolutely open to people of all nations and religions. Islamic banking does not restrict individual initiative, but it is linked to thorough ethical considerations, which are not respected in conventional banking. These advantages are becoming increasingly clear also to the westerners who have suffered a lot recently from the global financial crisis (Montaldo, 2009). The Islamic banking has become an actual alternative for many people who do not want to risk their funds by depositing them with regular banks (dspace.lu.lv). At the same time Islamic finance has been gaining momentum on a global scale, and has been offering profitable opportunities for institutions and individual investors of all sizes (www.innovationarabia.ae).

The purpose of the research is to identify how the Islamic banks, having inherited very old culture and religion based principles, have become important cobuilders of the modern world of finance, with a serious perspective for the nearest and long-term future.

To achieve the research purpose the following tasks were set forth:

*Kaspars Kḷavinš provided the culture and historical information as well as exact information in the related deliberations. Elias Abu Al Hija is responsible for the exact information provided in the article. The future prospects and conclusions are provided jointly by both authors. 
- research of related scientific literature and historical sources;

- analysis of global assets of Islamic finance industry;

- regional and time-based comparison of Islamic banking asset growth for the period of 2011-2013;

- study of the situation of Islamic banking in different countries of the world; banking.

- marking the actually foreseeable future growth prospects of the Islamic In order to show the prospects of such an alternative financial model, historical research, qualitative research methods as well as statistical analysis were used.

\section{INSIGHT INTO HISTORY}

Despite the recognition and reception of the role of the Middle East in European (and Western) astronomy, chemistry, mathematics, philosophy and poetics, the achievements of the Islamic world in finances and the economy were neglected for a very long time (Askari, Iqbal, \& Mirakhor, 2015). These matters were discussed in the past mostly by Western orientalists and not by professional economists or financiers. Regretfully, the Islamic economic tradition did not find an adequate reception and assessment in the context of Western social thinking either, because neither classical education nor the available materials made serious knowledge of the Middle East possible (Hobsbawm, 2013). Nevertheless, it has to be acknowledged that the economy of Islam was once one of the cornerstones for modernizing the goods-money relations in medieval Europe.

A very functional financial system, which was state-of-the-art against the background of the Middle Ages, was developed in the Arab (and Islamic) world, thus providing a positive methodology for the future banking system of the entire world, the evidence of which in the West is provided by the many financial terminology loans from the Arab language (including "cheque"). Also Sephardic Jews learned the basis of a modern financial organization in the Arab financial world during the Middle Ages, taking this knowledge further to Lisbon, Amsterdam, London and New York (Massignon, 1963).

The emergence of the underlying principles of Islamic banking can be understood by looking further back in the past. Although the first Islamic financial institutions were created during the modern period - namely in the $20^{\text {th }}$ century the idea and principle of Islamic economy is very old and has its roots already in the Islamic law (Quran and Sunnah). First of all, the business law of Islam prohibits usury (Riba) - riba technically refers to the "premium" that must be paid by the borrower to the lender along with the principal amount as a condition of the loan or for an extension in the duration of loan (Askari et al., 2015) - the most condemned form of which is renting money. "Money can be sold (exchanged) and can be invested in a business, but it cannot be rented" (Fazlun \& O'Brien, 1992). Like any device that impedes justice or equality in a transaction and which artificially reduces or increases the price of a thing is a crime in Islamic law (Fazlun \& O'Brien, 1992). According to the principles of Islamic economy, money should be loaned to those in need freely and without interest. The principles of social justice created a strong sense of responsibility between rich and powerful on one 
side and weak and poor people on the other. This undoubtedly contributed to social peace and stability in society.

Christianity, which became the most influential religion in the medieval Europe, did not accept usury either. In the Lord's Prayer (the "Our Father"), which Christians recite every day, the Latin version uses the words "debita nostra" ("forgive us our debts") (The New Testament: Matthew 6:12.), which has also to be understood in the literal sense, as taught by the Catechism of the Catholic Church. Since there was no clear provision in the "New Testament" regarding the taking of interest, the teachings on the prohibition against riba were taken from the "Old Testament" (The Old Testament: Ezekiel 18:17; Leviticus 25:37). The priests of Early Christianity in their sermons stressed that the practice of lending money at interest was evil because it violated the teachings of Christianity which supported the quality of benevolence (Haron, Nursofiza \& Azmi, 2009).

In Early Modern Europe the Middle East (and Arab) world even became a certain ideal, taking into account the intensified reception of ancient Arab science and the perception of this region as an ideal incarnation of public and social order. For example, Guillaume Postel in his "Turkish Letters" (1580s) (Kḷaviņš, 2015) praised the sense of equality and care for the poor in the Ottoman Empire. Memoirs of Reinhold Lubenau (1556-1631) upon the Turk and Arab traditions learned in Ottoman Empire specifically attracts attention to the transparency and honesty in Middle East markets, where goods were evaluated on a daily basis and any forgers were severely punished, as a result of which peasants could safely supply their products (Sahm, 1912). In the $16^{\text {th }}$ and $17^{\text {th }}$ centuries, Europe was still standing at the crossroads - in social, as well as cultural, scientific and religious areas. Its medieval foundation was shattered and many of the traditions (both in positive and negative sense) respected over centuries were questioned. Thus, the Father of Reformation Martin Luther (1483-1546) himself initially actively challenged hypocrisy and profligacy in the church and society, also by severely criticizing usury (Luther, 1540). The ideal of justice stood behind Reformation and Anabaptist activities, social justice was reflected in Jesuit thinking within the framework of Catholicism, it was supported by critical and tolerant thinkers, for example, Baruch Spinoza (1632-1677) and others. Usury was legalized in Western society only in the course of secularization which happened quickly in the $17^{\text {th }}, 18^{\text {th }}$ and $19^{\text {th }}$ centuries - alongside the development of capitalism. On the other side, it was always forbidden in Middle Eastern societies - until the French law legalized it as one of the most important principles in the modern financing model.

Despite many problems, there are several historical, cultural and demographic preconditions in Europe (and in the West in general) which could ensure introducing of financing principles similar to those of Islamic banking. Firstly, it is the prohibition of usury in Christianity, which fully corresponds to the condemnation of riba in Islam. Secondly, it is the long-standing Western tradition of social insurance - starting from the mutual aid societies in the guilds of medieval cities to modern savings banks (Germany, etc.). The primary function of these banks was not to enrich themselves but rather to encourage low-income people to save money and have access to banking services, to protect them in case of illness or accidents. 
The experience of modern Germany is especially successful in this respect, because it was the country where savings banks first emerged, and in turn, they later significantly influenced the pioneers of Islamic banking. Ahmad an-Naddschār (1932-1996) studied in Germany for a while and defended his $\mathrm{PhD}$ at the University of Cologne. There he became acquainted with the tradition of savings banks ("Sparkassen") and used it as the basis for the creation of the modern technological concept of Islamic banking, on which all the subsequent development of this financial system was based. Alongside the savings banks, also the Islamic banks gain more and more influence in today's Germany (KT Bank AG).

\section{SIZE OF ISLAMIC FINANCE}

The contribution of the Islamic economy to the world economy has experienced a remarkable growth during the past three decades. The size of Islamic economy is reaching US\$2.3 trillion and a growing community of 1.6 billion Muslims (Mustafa \& Kḷavinšs, 2015). The significant growth of the Muslim community in Europe as a result of higher birth-rates and even more of the migration of refugees is a serious factor in the growth of the Islamic banking sector. Driven by immigration and high birth rates, the number of Muslims on the continent has tripled in the last 30 years. According to forecasts, most demographers expect also a high rate of growth in the coming decades. By contrast, Europe's native population is rapidly ageing and beginning to decline in absolute numbers. The Muslim population in the EU, Norway and Switzerland is expected to increase by more than $55 \%$ in the next 21 years, rising from estimated 23.10 million in 2014 to 36.50 million by 2035 (Mustafa \& Kḷaviņš, 2015).

The current size of global Islamic finance industry assets is approaching US\$ 2.1 trillion in contrast to more than US\$ 7 trillion of GDP (gross domestic product) regarding the economies of the OIC (Organisation of Islamic Cooperation) countries (Augustin, 2016), and is expected to reach US\$ 4 trillion by 2020 (Kassem, 2015). The Islamic finance industry is also said to be growing rates (10\% to $15 \%$ p.a.), (15\% to $20 \%$ p.a.) per annum (www.kantakji.com).

To have a better understanding, recent past of Islamic banking asset growth dynamics has to be looked at. Figure 1 presents this global development for the period from 2011 to 2013.

According to the information presented and calculated in Fig. 1, Islamic banking has rapidly become a global player not only in Muslim countries, of which states of the Gulf Cooperation Council (GCC) are traditionally recognised as the success story of this sector - the expansion in the rest of the world shows that this principle of financing is actively joined by people from Western countries, too. More than 350 Islamic banks and financial institutions are now operating in over 60 countries in different regions, including Switzerland, the United States of America, France, Germany, Thailand, Singapore, India, China and Australia. Top 10 global banks in Islamic finance are shown in Table 1. 


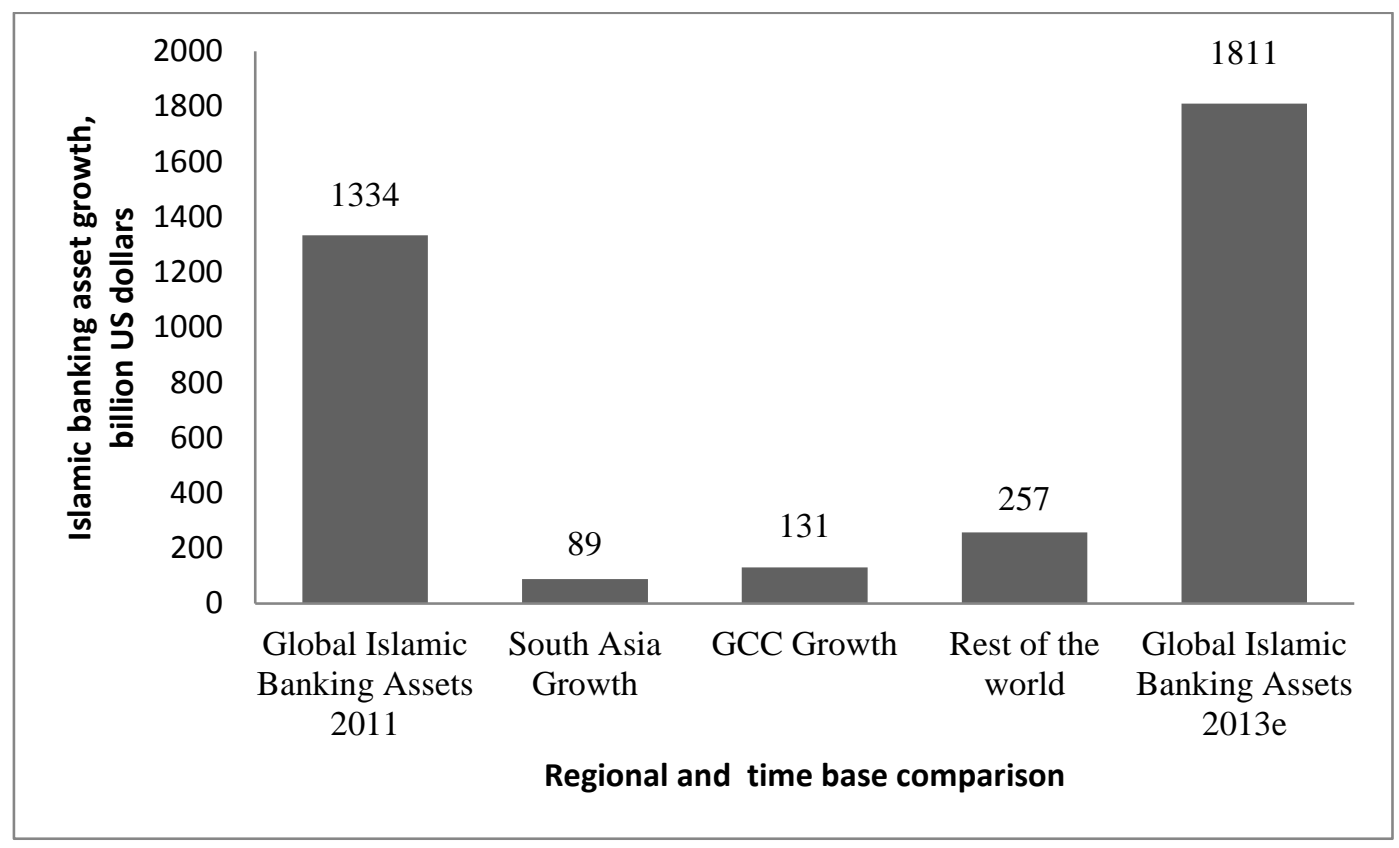

Fig. 1. Islamic banking asset growth in billion US dollars. (Calculation by the authors).

Table 1. Top 10 global banks in Islamic finance (Institute of Islamic Banking and Finance - AIMS UK, 2013)

\begin{tabular}{|l|c|}
\hline UBS & Switzerland \\
\hline Citigroup & USA \\
\hline Mizuho Financial Group & Japan \\
\hline HSBC Holding & UK \\
\hline Credit Agricole Group & France \\
\hline BNP Pariba & France \\
\hline JP Morgan Chase \& Co & USA \\
\hline Deutsche Bank & Germany \\
\hline Royal Bank of Scotland & UK \\
\hline Bank of America & USA \\
\hline
\end{tabular}

The information provided in Table 1 shows that global banks in Islamic finance represent the developed countries of the world, which proves the stability, predictability, safety and responsible behaviour of Islamic banking.

Today, many other countries are trying to be the centre of Islamic banking and finance. Such a conclusion follows from, e.g. the information provided by Institute of Islamic Banking and Finance - AIMS UK, 2013:

Britain is becoming an Islamic banking hub with five Islamic banks in London regulated by the FSA. 
Germany potentially is a big market for Islamic finance, taking into account the tradition of social thinking as well as the high percentage of Muslim population.

France woke up recently to be a part of the Islamic banking and finance bandwagon.

In Russia the principles of Islamic economy are being seriously studied, taking into account the experience of Islamic banking within the current reform process of the financial system.

Canada is looking into regulatory issues of accommodating Islamic banking and finance institutions.

Singapore is competing with Malaysia on the Islamic banking front and has housed the first Asian Islamic Bank.

Thailand already has the Islamic Bank of Thailand, backed by the government to attract FDIs through Islamic finance, to develop the nation.

Hong Kong is aspiring to be an Islamic banking Hub and is moving positively in this direction.

India is an emerging market for Islamic finance.

Japan is building appetite for Islamic Finance through the debut Sukuk offering.

Indonesia has fine tuning regulatory framework for intensive pursuit of Islamic banking and finance in its mainstream operations.

Similar to the conventional financial system, Islamic banking sector performs broad functions that may influence savings and investment decisions and hence could have implications for real economic growth.

A short analysis of the Islamic banking development in the UAE from 2005 to 2013 is provided in Table 2.

Table 2. Islamic banking in UAE: 2013, thousands US Dollar, USD,

(The World Bank, n.d.)

\begin{tabular}{|c|c|c|c|c|c|c|}
\hline Year & $\begin{array}{c}\text { Total } \\
\text { Assets }\end{array}$ & $\begin{array}{c}\text { Total } \\
\text { Deposits }\end{array}$ & $\begin{array}{c}\text { Total } \\
\text { Liabilities }\end{array}$ & $\begin{array}{c}\text { Total Share- } \\
\text { holders } \\
\text { Equity }\end{array}$ & $\begin{array}{c}\text { Total } \\
\text { Investments }\end{array}$ & Total Income \\
\hline 2013 & 88214629 & 62316034 & 76475611 & 11157711 & 62151181 & 3343653 \\
\hline 2012 & 79863846 & 56640746 & 69518002 & 10044792 & 56688461 & 3022487 \\
\hline 2011 & 56675865 & 40854526 & 49425317 & 6955293 & 44368623 & 2356756 \\
\hline 2010 & 59305818 & 42587193 & 52044287 & 6978189 & 46865125 & 2079489 \\
\hline 2009 & 56380607 & 42583407 & 49576133 & 6777209 & 47634450 & 2179564 \\
\hline 2008 & 53477596 & 40069779 & 47435322 & 6016240 & 46962727 & 2207015 \\
\hline 2007 & 45515815 & 33485152 & 39609070 & 5837626 & 40200071 & 1979344 \\
\hline 2006 & 32359341 & 22992627 & 28365038 & 3915785 & 29103343 & 1221363 \\
\hline 2005 & 20491184 & 15734211 & 18091430 & 2366544 & 17933736 & 801219 \\
\hline
\end{tabular}


According to the Table 2, there is an increase in the total assets in the UAE for the Islamic banking: in 2005 the total assets were US\$ 20491184 while they increased to US\$ 88214629 in 2013 which means that the total assets increased by $330 \%$. While the total investment increased from US\$ 17933736 in 2005 to US\$ 62151181 in 2013, i.e. by $247 \%$, which means that there are a lot of investment projects financed from the Islamic banking. Islamic banks in the Middle East and all over the world in general invest in long term infrastructure projects, small and medium enterprises, micro ventures, social projects, medicine, etc. Upon making investments, the most acute needs of the society are respected. It should be taken into account that presently there are 90 million consumers of Islamic banks all over the world (Augustin, 2016), and their number will certainly increase in the nearest future.

\section{CONCLUSION}

The prospects of the Islamic banking are improving with the growing insecurity of the global financial system and diminishing responsibility of traditional banks towards their investors. A real cover for investments, prohibition of trade in substances harmful to people - all of these also promote stabilisation of the population on our planet, taking into account that social unrest and radicalisation often result from unstable economic situation. In Europe, the principles of Islamic banking are also easily understandable thanks to the old tradition of social thought and persistent search of alternatives which has characterised the brightest minds of Europeans for centuries. In this respect, the Islamic banking offers a ready and carefully developed model, easily accessible to all interested persons and potential investors. Global financial processes are closely linked to economic and demographic processes, price fluctuations, etc. Likewise, the Islamic banking does not exist in isolation from these processes, nevertheless, it is the ethical principles followed by the Islamic banking and its reasonable restrictions which can become the pledge of trust and success. Alongside the success of Islamic banking, potential growth in the near future can also be expected in connection with strengthening and expansion of this financial system in the Middle and Far East. The countries of the Persian Gulf, like the United Arab Emirates, are a vivid example.

\section{DISCLOSURE STATEMENT}

The authors declare that they do not have any competing, financial, professional, or personal interests.

\section{REFERENCES}

Askari, H., Iqbal, Z., \& Mirakhor, A. (2015). Introduction to Islamic Economics: Theory and Application. Singapore: John Wiley \& Sons.

Augustin, B. D. (2016, May 23). Call for strong Islamic banking rules. Gulf News.

Fazlun, M. K., \& O'Brien, J. (1992). Islam and Ecology. London: World Wide Fund of Nature.

Haron, S., \& Nursofiza, W. (2009). Islamic Finance and Banking System. Kuala Lumpur: McGrawHill. 
Hobsbawm, E. (2013). How to Change the World, Tales of Marx and Marxism. London: Abacus. Institute of Islamic Banking and Finance - AIMS UK. (2013). Retrieved from http://www.aims.education/islamic-banking-and-finance-institute/

Kassem, M. (2015). Islamic banking assets to reach \$1 trillion milestone by end-2015. The National. Retrieved from http://www.thenational.ae/business/banking/islamic-banking-assets-to-reach-1trillion-milestone-by-end-2015

Kḷaviņš, K. (2015). The Importance of Islamic Civilization at the Crossroads of European Thinkers: 16 th and 17th centuries. Scholarly Papers, 803, 66-78.

KT Bank AG (Germany) (n.d.). Retrieved from https://www.kt-bank.de/ueber-uns/kt-bank/

Luther, M. (1540). An die Pfarrherrn Wider den Wucher zu predigen. Vermanung D. Martini Luther. Wittemberg: Joseph Klug.

Massignon, L. (1963). Opera minora, I. Beirut: Dar Al-Maaref.

Montaldo, J. (2009). Lettreouverte aux bandits de la finance. Paris: Albin Michel.

Mustafa, H., \& Kḷaviņš, K. (2015). Muslim Population in Europe: Prospects for Integration. Scholarly Papers, 803, 79-86.

Sahm, W. (1912). Beschreibung der Reisen des Reinhold Lubenau, 1. Teil. Königsberg i. Pr.: Kommissions-Verlag von Ferd. Beyers Buchhandlung.

The New Testament: Matthew 6:12.

The Old Testament: Ezekiel 18:17; Leviticus 25:37.

The World Bank. (n.d.). Retrieved from http://data.worldbank.org/

\section{AUTHORS' SHORT BIOGRAPHIES}

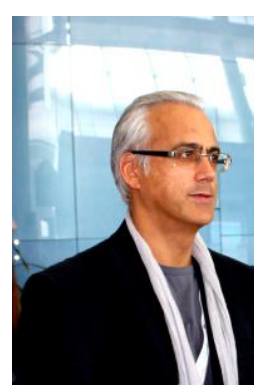

Kaspars Kḷaviņš is a Professor with Faculty of Engineering Economics and Management, Riga Technical University, Latvia. He received his Doctor's degree in History from the University of Latvia. He has been a Visiting Professor at the Roosevelt University (USA) (the Fulbright Scholarship), an Adjunct Research Associate at Monash University (Australia), a Research Associate at the University of Reading (Department of Archaeology) (UK), Visiting Professor at the University of Münster (Germany) and a Professor of History and Cross-Cultural Management at the Emirates College of Technology in Abu Dhabi (United Arab Emirates).

$\mathrm{K}$. Kļaviņš is the author of 10 scientific monographs, a number of chapters in different books and fundamental historical source publications, as well as the author of many scientific articles (including articles in English, French, German and Arabic).

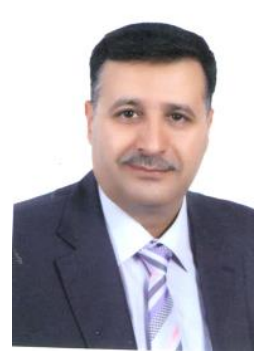

Elias Abu AL-Haija received his Doctor's degree in Economics and Islamic Banking from the Yarmouk University, Jordan. Dr. Elias's research focuses on Islamic Banking and Finance. His articles are published in peer reviewed international journals, the last one including Financial Development, Islamic Finance and Economic growth. The courses Dr. Elias teaches include Finance, Banking, Economic, and Islamic Banking. Prior to joining ECT, Dr. Elias worked as a Director of Risk Management Department at Jordan Islamic Bank for more than twenty years. He is a professional trainer in many fields including Islamic banking and Finance at many training centres in Jordan, SA, and UAE. Dr. Elias is also a consultant in the field of Islamic Banking development. He currently works as a faculty member in the Banking and Finance Department at Emirates College of Technology Abu Dhabi, UAE. 